\title{
Paracrine renal endothelin system in rats with liver cirrhosis
}

\author{
1,*,†Berthold Hocher, $\nmid$ Rüdiger Zart, *Fritz Diekmann, ** Peter Rohmeiss, \#Armin Distler, \\ *Hans H. Neumayer, $\uparrow$ Christian Bauer \& \#Peter Gross
}

Departments of Nephrology, *Universitätsklinikum Charité der Humboldt Universität zu Berlin, **Klinikum Mannheim, University of Heidelberg and \#Universitätsklinikum Benjamin Franklin, Free University of Berlin, and Institute of Molecular Biology and Biochemistry, Free University of Berlin, Germany

1 Liver cirrhosis was induced in rats by $\mathrm{CCl}_{4}$ administration. We analysed the expression of endothelin receptor subtypes in the renal cortex and medulla using Scatchard analysis and receptor autoradiography, and measured plasma as well as renal-tissue endothelin-1 concentrations using a specific radioimmunoassay. Furthermore, we analysed the effects of the non-selective (A/B) endothelin receptor antagonist, bosentan $\left(6\right.$ and $\left.100 \mathrm{mg} \mathrm{kg}^{-1} \mathrm{day}^{-1}\right)$ on mean arterial blood pressure, water and sodium excretion and glomerular filtration rate.

2 Our study revealed an overexpression of the endothelin B receptor $\left(\mathrm{ET}_{\mathrm{B}}\right)$ in the renal medulla of rats with liver cirrhosis (Cir: $2775 \pm 299 \mathrm{fmol} \mathrm{mg}^{-1}$; Con: $1695 \pm 255 \mathrm{fmol} \mathrm{mg}^{-1} ; n=8$; means \pm s.d., $P<0.01$ ), whereas the density of $\mathrm{ET}_{\mathrm{B}}$ in the cortex and the endothelin $\mathrm{A}$ receptor $\left(\mathrm{ET}_{\mathrm{A}}\right)$ in the cortex and medulla were similar in both cirrhotic and control rats. Receptor autoradiography showed that the upregulation of medullary $\mathrm{ET}_{\mathrm{B}}$ in cirrhotic rats was due to an upregulation of $\mathrm{ET}_{\mathrm{B}}$ in the inner medullary collecting duct cells.

3 The tissue endothelin-1 concentrations were increased in the renal medulla of cirrhotic rats (Cir:271 \pm 68 pg g $^{-1}$ wet wt.; Con: $153 \pm 36$ pg g $^{-1}$ wet wt., $n=8$; means \pm s.d., $P<0.01$ ).

4 The glomerular filtration rate was slightly decreased in cirrhotic rats but not altered after bosentan treatment in either cirrhotic or control rats. Bosentan decreased sodium excretion to a similar extent in both cirrhotic and control rats, whereas water excretion was significantly reduced by both dosages of bosentan in cirrhotic rats only (Cir + vehicle: $12.5 \pm 0.62 \mathrm{ml} \mathrm{day}^{-1}, \mathrm{Cir}+6 \mathrm{mg} \mathrm{kg}^{-1} \mathrm{day}^{-1}$ bosentan: $8.6 \pm 1.0 \mathrm{ml} \mathrm{day}^{-1}$; $\mathrm{Cir}+100 \mathrm{mg} \mathrm{kg}{ }^{-1}$ day $^{-1}$ bosentan:7.4 $\pm 0.6 \mathrm{ml} \mathrm{day}^{-1} ; n=10$; means \pm s.e.mean).

5 We therefore suggest that the upregulation of the medullary ET $_{B}$ in cirrhotic rats is involved in the regulation of water excretion in rats with $\mathrm{CCl}_{4}$-induced liver cirrhosis.

Keywords: Endothelin; endothelin receptor antagonist; bosentan; liver cirrhosis; paracrine renal endothelin system; kidney dysfunction in liver cirrhosis

\section{Introduction}

Endothelins (ET-1, ET-2 and ET-3), a family of 21 amino acid peptides thought to regulate local vasomotor tone, are the most potent vasoconstrictor substances yet identified. Endothelin-1 was the first of the isopeptides to be characterized in the supernatant of cultured vascular endothelial cells (Yanagisawa et al., 1988). The biological effects of endothelin are mediated by plasma-membrane-bound receptors. Three endothelin receptor subtypes $\left(\mathrm{ET}_{\mathrm{A}}, \mathrm{ET}_{\mathrm{B}}\right.$ and recently $\mathrm{ET}_{\mathrm{C}}$ ) have been cloned (Arai et al., 1990; Haendler et al., 1992; Kumar 1994). They belong to the family of rhodopsin-like receptors coupled to a G-protein and differ in their binding affinity to endothelin isopeptides $\left(\mathrm{ET}_{\mathrm{A}}\right.$ : ET-1 $\geqslant$ ET-2 $>>$ ET-3; $\mathrm{ET}_{\mathrm{B}}$; ET$1=\mathrm{ET}-2=\mathrm{ET}-3, \mathrm{ET}_{\mathrm{C}}$ : ET-3 $>>\mathrm{ET}-2=\mathrm{ET}-1$ ) as well as in their expression by different cell types. Apart from their vasoactive (Lüscher et al., 1993) and renal properties (Gross et al., 1993), endothelins have been shown to induce a wide variety of biological activities in non-vascular tissues (for reviews, see Leppaluoto et al., 1992; Sokolovsky, 1992; Lüscher et al., 1993), including the liver (Gandhi et al., 1992; 1993).

It is well known that plasma endothelin concentrations are significantly increased in rats as well as patients with liver cirrhosis and ascites and that these high ET-1 concentrations

\footnotetext{
${ }^{1}$ Author for correspondence at: Universitätsklinikum Charité der Humboldt Universität zu Berlin, Abteilung für Nephrologie (Medizinische Klinik 5), Schumannstr. 20-21, 10098 Berlin, Germany.
}

are associated with kidney dysfunction (Claria et al., 1991a; Asbert et al., 1993; Uchihara et al., 1992; Moller et al., 1993; Nanji et al., 1994).

Since endothelin is mainly a paracrine acting hormone and there have been no studies so far concerning the paracrine renal endothelin system in liver cirrhosis, the aim of our study was to analyse the expression of endothelin receptor subtypes and endothelin synthesis in the kidney of rats with $\mathrm{CCl}_{4}$-induced liver cirrhosis and ascites. Furthermore, we have analysed the function of the paracrine renal endothelin system in cirrhotic rats using the orally active mixed (A/B) endothelin receptor antagonist, bosentan (Clozel et al., 1994).

\section{Methods}

\section{Blood-pressure measurement}

To measure arterial blood pressure, the rats were placed in a retaining box and warmed until a pulse was detected in the tail. Systolic pressure was measured with a tail cuff and a pressure transducer in conjunction with an automatic pressure delivery system and chart recorder (Harvard indirect rat-tail bloodpressure system, Harvard Apparatus Ltd., Edenbridge, England).

\section{Animals and treatment}

All animal experiments were conducted in accordance with local institutional guidelines for the care and use of laboratory 
animals. Male Wistar rats (WKY, Møllegard, Denmark) were maintained on standard laboratory chow (Altromin, Altromin $\mathrm{GmbH}$, Germany) and tap water ad libitum with a $12 \mathrm{~h}$ lightdark cycle at constant temperature and humidity. At the time of the experiment, rats weighed about $350 \mathrm{~g}$.

\section{Induction of liver cirrhosis}

The liver cirrhosis was induced according to McLean et al. (1969). The rats received phenobarbitone water at a concentration of $3 \mathrm{~g}^{-1}$ and were exposed to $\mathrm{CCl}_{4}$ by inhalation. A box with a transparent cover (150 l capacity) was fitted with an inlet tap. Compressed air was passed into the box via a flow meter (Kendal, Neustadt, Germany), at $21 \mathrm{~min}^{-1}$, bubbling through two wash bottles containing $\mathrm{CCl}_{4}$. Air left the box by leaking through the joints. At each dose, the $\mathrm{CCl}_{4}$ vapour was run in for $5 \mathrm{~min}$ and then turned off, and the rats were left in the box for $5 \mathrm{~min}$. This was repeated twice weekly. The rats were treated with $\mathrm{CCl}_{4}$ inhalation twice a week for 9 weeks. The control rats of the same age and sex were not treated.

\section{Treatment with the mixed $(A / B)$ endothelin receptor antagonist, bosentan}

The rats were divided into six age-matched groups. All 6 groups were of 10 rats and treated during 2 days, and bosentan was always freshly prepared and administered as micronized free sulphonamide by gastric gavage. Vehicle was $5 \%$ arabic gum. Group I: Control rats without bosentan treatment, the rats received vehicle only. Group II: Control rats with bosentan treatment $\left(6 \mathrm{mg} \mathrm{kg}^{\times 1} \mathrm{day}^{-1}\right)$. Group III: Control rats with bosentan treatment $\left(100 \mathrm{mg} \mathrm{kg}^{-1} \mathrm{day}^{-1}\right)$. Group IV: Rats with $\mathrm{CCl}_{4}$ cirrhosis not submitted to bosentan treatment; the rats received vehicle. Group $V$ : Rats with $\mathrm{CCl}_{4}$ cirrhosis with bosentan treatment $\left(6 \mathrm{mg} \mathrm{kg}^{-1}\right.$ day $\left.^{-1}\right)$. Group VI: Rats with $\mathrm{CCl}_{4}$ cirrhosis and with bosentan treatment $\left(100 \mathrm{mg} \mathrm{kg}^{-1} \mathrm{day}^{-1}\right)$.

Urine was collected for the determination of $\mathrm{pH}$ sodium, potassium and creatinine. All rats were killed after $48 \mathrm{~h}$. Blood samples were collected from the inferior vena cava. The liver was removed quickly. Liver samples for tissue extraction of ET-1 and Scatchard analysis were frozen immediately in liquid nitrogen and stored at $-70^{\circ} \mathrm{C}$ until further use.

\section{Light microscopy}

Tissue was obtained from the middle lobe of the liver of each animal. Pathohistological evaluation of the liver morphology (haematoxylin-eosin and elastica van Gieson staining) were performed on all tissue blocks.

\section{Serum enzymes (clinical chemistry) and glomerular filtration rate}

Serum levels of potassium, sodium, aspartate transaminase (AST), alanine transaminase (ALT), lactate dehydrogenase (LDH) and bilirubin were measured with the appropriate kits in an automatic analyzer. Blood samples for the determination of serum enzymes were drawn at the end of the experiment.

Measurement of the glomerular filtration rate The GFR was measured by the inulin single-shot method (Gretz et al., 1990) after $24 \mathrm{~h}$ of treatment with bosentan or vehicle (see above). The single-shot clearance was evaluated by displaying a twocompartment model with resolution of the plasma inulin concentrations into two monoexponential functions. The rats received an intravenous i.v. bolus injection of $150 \mathrm{mg}$ of inulin (Inutest). Blood samples for determination of serum inulin concentrations were drawn at $0,30,90,135$ and 180 min after injection. Inulin was measured by a modified $\beta$-fructosidase method (Kühnle et al., 1992). GFR is expressed as $\mathrm{ml} \mathrm{min}^{-1}$ $100 \mathrm{~g}^{-1}$ body weight.

\section{Endothelin-1 radioimmunoassay}

Tissue preparation Liver- and kidney-tissue-immunoreactive endothelin levels were measured by a method described by Bolger et al. (1991). After thawing, liver samples were suspended in $2 \mathrm{ml} \mathrm{g}^{-1}$ wet wt. of $0.2 \mathrm{M}$ acetic acid, $0.5 \mathrm{M} \mathrm{NaCl}$, disrupted with a polytron and subsequently homogenized. The homogenate was centrifuged at $4^{\circ} \mathrm{C}$ for $15 \mathrm{~min}$ at $25,000 \mathrm{~g}$. The supernatant was stored for endothelin-1 radioimmunoassay and the pellet discarded.

Radioimmunoassay Immunoreactive endothelin-1 (irET-1) was extracted from tissue supernatant using Amprep $500 \mathrm{C} 2$ columns (Amersham). One-ml samples were acidified with $0.25 \mathrm{ml}$ of $2 \mathrm{M} \mathrm{HCl}$, centrifuged at $10,000 \mathrm{~g}$ for $5 \mathrm{~min}$ at room temperature and loaded onto the columns. The columns were washed with $5 \mathrm{ml}$ of water and $0.1 \%$ trifluoracetic acid (TFA), and the adsorbed peptide was eluted with $2 \mathrm{ml}$ of $80 \%$ methanol in water and $0.1 \%$ TFA. The eluents were collected in polypropylene tubes and dried under a stream of nitrogen. The probes were reconstituted in $250 \mu \mathrm{l}$ of assay buffer $(0.02 \mathrm{M}$ borate buffer, $\mathrm{pH} 7.4$, containing $0.1 \%$ sodium azide), and $2 \times 100 \mu \mathrm{l}$ were taken for analysis in a commercial endothelin- ${ }^{125}$ I radioimmunoassay kit (Endothelin-1,2 (high sensitivity) ${ }^{125}$ I assay system, Amersham). Separation of the antibody-bound fraction was effected by magnetic separation with the Amerlex-M Separator (Amersham). This assay reacts $100 \%$ with ET-1 and cross-reacts $189 \%$ with ET-2. Cross-reactivity with ET-3 was less than 0.001 .

\section{ETA/ETB-receptor-binding experiments}

Membrane preparation Membranes were prepared according to Nambi et al. (1990) and Hocher et al. (1995) with minor modifications. Approximately $0.3 \mathrm{~g}$ of the kidney was homogenized at $4^{\circ} \mathrm{C}$ in $20 \mathrm{ml}$ of $20 \mathrm{mmol}^{-1} \mathrm{NaHCO}_{3}$ with a motordriven pestle homogenizer. The homogenate was centrifuged at $4^{\circ} \mathrm{C}$ for $15 \mathrm{~min}$ at $1000 \mathrm{~g}$. The supernatant was decanted and centrifuged at $4^{\circ} \mathrm{C}$ for $30 \mathrm{~min}$ at $40,000 \mathrm{~g}$. The pellet, consisting of crude plasma membranes, was resuspended in assay buffer (100 mM Tris- $\mathrm{HCl}, 5 \mathrm{mM} \mathrm{MgCl}$, and $0.1 \mathrm{~g} \% \mathrm{BSA}, \mathrm{pH}$ 7.4) at a protein concentration of $200 \mu \mathrm{g} \mathrm{ml}^{-1}$. Protein content was determined according to the method of Lowry et al. (1951) with bovine serum albumin used as a standard.

Binding assays In order to analyse the expression of endothelin receptor subtypes (ETA/ETB) in the kidney, binding assays were performed in the presence or absence of the subtype-specific endothelin receptor ligands, BQ123 $(3 \mu \mathrm{M})$ and/or BQ3020 (3 $\mu \mathrm{M})$ (Nambi et al., 1992). The assay buffer for binding studies contained $1 \mathrm{mg} \mathrm{ml}^{-1}$ bacitracin, $100 \mathrm{mM}$ Tris- $\mathrm{HCl}, 5 \mathrm{mM} \mathrm{MgCl}_{2}$, and $0.1 \mathrm{~g} \% \mathrm{BSA}$, $\mathrm{pH} 7.4$, in a total volume of $150 \mu \mathrm{l}$. The [ $\left.{ }^{125} \mathrm{I}\right]-\mathrm{ET}-1$ tracer concentration was kept constant at 40,000 c.p.m./tube, while the concentration of unlabelled ET-1 was increased from 0 to $25 \mathrm{nM}$ (competition studies with 'cold saturation'). Samples from crude plasma membranes were used at a concentration of $0.53 \mathrm{mg}$ protein $\mathrm{ml}^{-1}$ according to Hocher $e t$ al. (1992b, 1995). Binding studies were performed at room temperature for $120 \mathrm{~min}$. Non-specific binding was assessed in the presence of excess ET-1 $(5 \mu \mathrm{M})$. After adding $1 \mathrm{ml}$ of cold binding buffer, free and receptor-bound radioactivity was separated by centrifugation at $30,000 \mathrm{~g}\left(4^{\circ} \mathrm{C}\right)$ for $15 \mathrm{~min}$, and the pellets thus obtained were washed two additional times with $1 \mathrm{ml}$ of cold binding buffer. ${ }^{125} \mathrm{I}$ was counted in a Packard Gamma Counter ( $78 \%$ counting efficiency for $\left.{ }^{125} \mathrm{I}\right)$.

\section{Autoradiography of tissue endothelin receptor subtypes}

In vitro receptor autoradiography was performed according to Hocher et al. (1992a; 1995) with minor modifications. The 
frozen kidneys was cut into $5 \mu \mathrm{m}$ thick sections with a microtome-cryostat. The sections were placed on precooled slides, air-dried for $10 \mathrm{~min}$ and stored at $-20^{\circ} \mathrm{C}$. Autoradiographic incubation was performed in the presence or absence of subtype specific endothelin receptor ligands BQ123 $\left(3 \mu \mathrm{mmol}^{-1}\right)$ and/or BQ3020 $\left(3 \mu \mathrm{mmol} 1^{-1}\right)$. The slides were covered with $100 \mu \mathrm{l}$ binding buffer $\left(1 \mathrm{~g} \mathrm{l}^{-1}\right.$ bacitracin, $100 \mathrm{mmol}^{-1}$ Tris- $\mathrm{HCl}, 5 \mathrm{mmol} 1^{-1} \mathrm{MgCl}_{2}$, and $1 \mathrm{~g} \mathrm{l}^{-1}$ bovine serum albumin, $\mathrm{pH} 7.4)$ containing $\left[{ }^{125} \mathrm{I}\right]-\mathrm{ET}-1$ in a concentration of $50 \mathrm{pM}\left(24000\right.$ d.p.m. $\left.100 \mu \mathrm{l}^{-1}\right)$ and incubated in a moist chamber for $2 \mathrm{~h}$ at room temperature. Radioactivity was withdrawn by suction with a vacuum pump and the slides were washed 4 times for $10 \mathrm{~min}$ in $4^{\circ} \mathrm{C}$ cold binding buffer. Finally the sections were fixed for $20 \mathrm{~min}$ in $5 \%$ formalin, $2.5 \%$ glutaraldehyde, $0.9 \% \mathrm{NaCl}$. To remove residual buffer the slides were briefly dipped in distilled water. Autoradiograms with both endothelin receptor ligands (BQ123, BQ3020) served as a control. The sections were layered with photoemulsion (K5 nuclear trace emulsion, Ilford, Germany) and stained with haematoxylin and eosine. Evaluation was done by counting the silver grains.

\section{Chemicals}

$\left[{ }^{125} \mathrm{I}\right]-\mathrm{Tyr}^{13}$-endothelin-1 ([ $\left.\left.{ }^{125} \mathrm{I}\right]-\mathrm{ET}-1\right)\left(2200 \mathrm{Ci} \mathrm{mmol}^{-1}\right)$ was obtained from Du Pont, Germany. Unlabelled ET-1 was from Peninsula Laboratories, Inc. (Germany). The mixed (A/B) endothelin receptor antagonist, bosentan (4-tert-butyl-N-(2hydroxy-ethoxy)-5-(2-methoxy-phenoxy)-2,2'-bipyrimidine-4yl\}-benzenesulphonamide) was a generous gift from Dr Martine Clozel (F. Hoffmann-La Roche Ltd, Basel, Switzerland). The selective endothelin receptor ligands (BQ123 and BQ3020) were purchased from California Peptides Inc. (U.S.A.). $\mathrm{CCl}_{4}$ was obtained from Merck (Darmstadt, Germany). Kits for radioimmunoassays (RIA) of ET-1 were purchased from Amersham (Braunschweig, Germany).

Unless otherwise stated, all reagents were of analytical grade and were purchased from Merck (Darmstadt, Germany), Boehringer-Mannheim (Mannheim, Germany) and Sigma (München, Germany).

\section{Statistical analysis}

Statistically significant differences among individual groups were determined by Student's unpaired $t$ test.

\section{Results}

The liver histology of all rats treated with $\mathrm{CCl}_{4}$ showed micronodular cirrhosis (Figure 1). All these animals also had
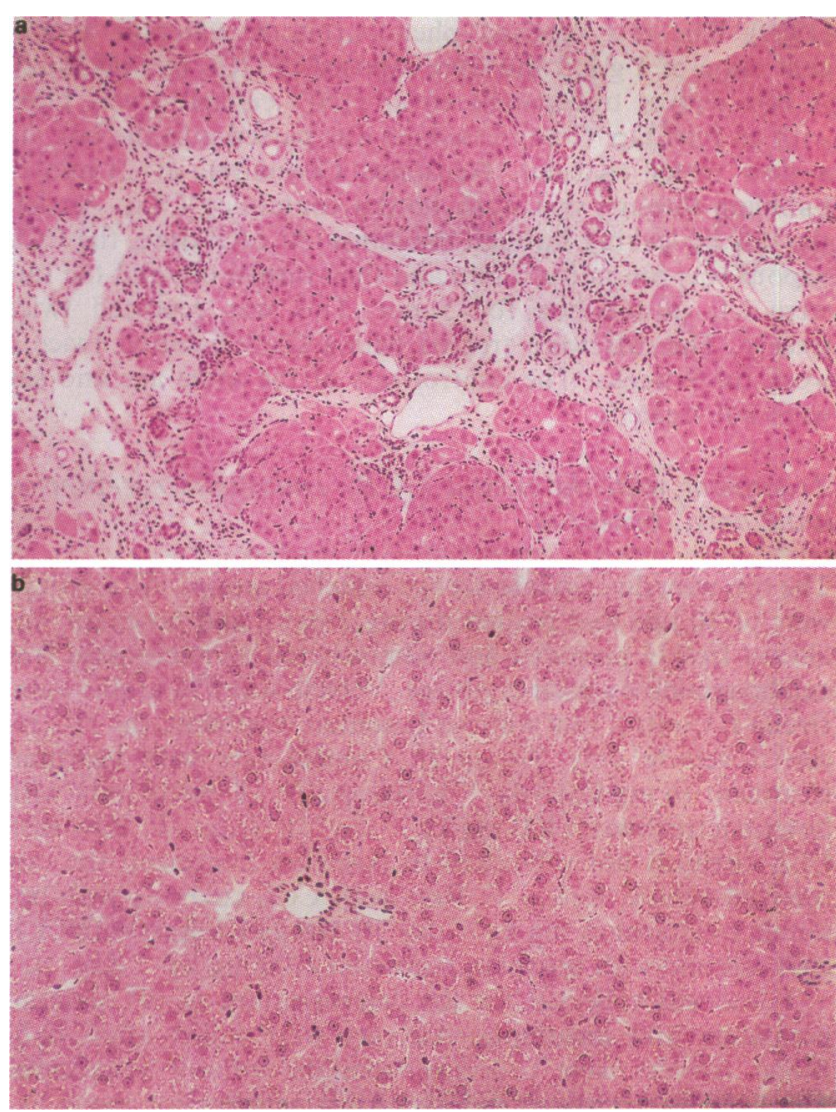

Figure 1 Micronodular liver cirrhosis in the rats treated with phenobarbitone water and $\mathrm{CCl}_{4}$ inhalation for 9 weeks (a); normal rat liver served as control (b). Calibration bar $=$ (original magnification $166 \times$ ).

Table 1 Serum enzyme activities, sodium-, potassium- and bilirubin-concentrations, blood pressure and glomerular filtration rate in control and cirrhotic rats

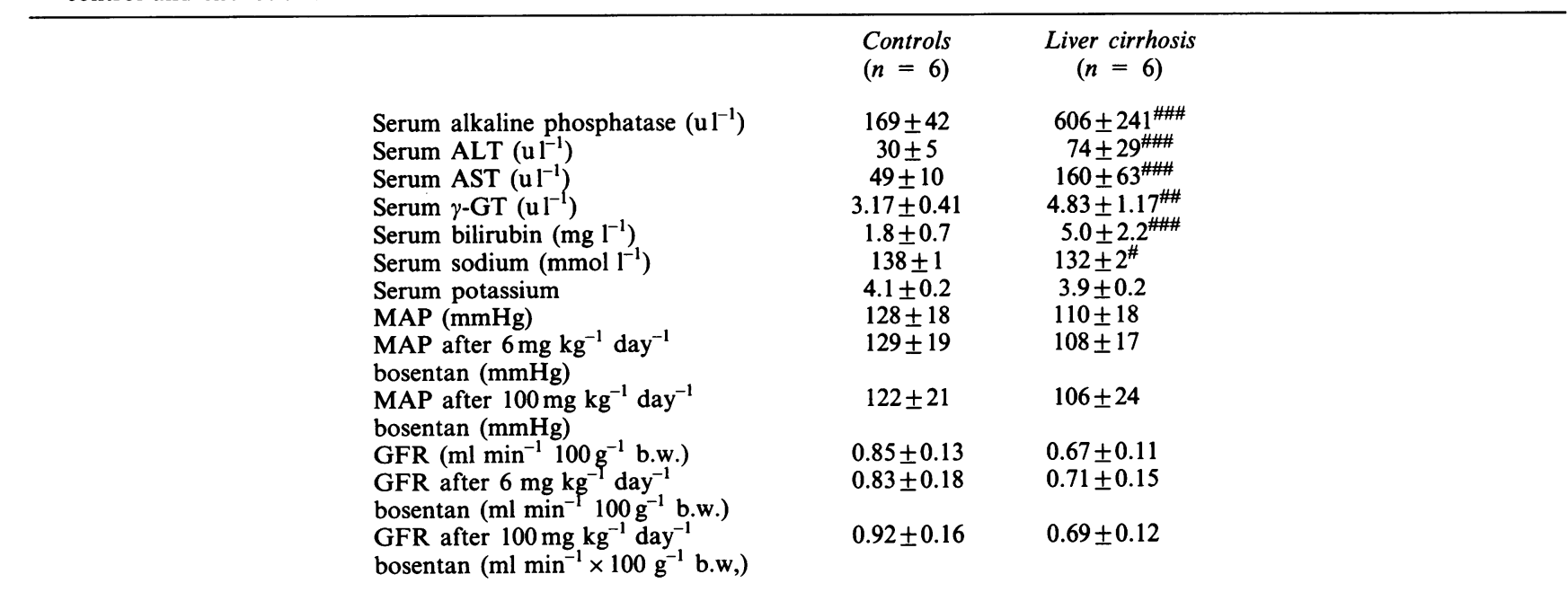

Serum levels of sodium, potassium and aspartate transamine (AST), alanine transaminase (ALT), alkaline phosphatase and bilirubin were measured using the appropriate kits in an automatic analyser. MAP: mean arterial blood pressure (mmHg), GFR: glomerular filtration rate. The mixed (A/B) endothelin receptor antagonist bosentan $\left(6\right.$ or $100 \mathrm{mg} \mathrm{kg}^{-1}$ day $\left.^{-1}\right)$ was given by gastric gavage. Values are means \pm s.d.; ${ }^{\#} P<0.05,{ }^{\#} P<0.01 ;{ }^{\# \#} P<0.005$, compared to control rats. 
ascites at the time of the study, the ascites volume ranging from 2 to $28 \mathrm{ml}$. Control rats had a normal liver histology and no ascites. Plasma bilirubin was increased in the cirrhotic rats (Table 1). Blood pressure was slightly decreased in cirrhotic rats compared to control rats. The mixed (A/B) endothelin receptor antagonist, bosentan, did not decrease blood pressure in control and cirrhotic rats (Table 1). Scatchard analysis revealed an overexpression of the endothelin $B$ receptor $\left(E_{B}\right)$ in the renal medulla of rats with cirrhosis (Cir; $B_{\max }$ : $2775 \pm 299 \mathrm{fmol} \mathrm{mg}^{-1}$; Con; $B_{\max }$ : $1695 \pm 255 \mathrm{fmol} \mathrm{mg}^{-1} ; n=8 ; P<0.01$, whereas the density of the $\mathrm{ET}_{\mathrm{B}}$ in the cortex and of the endothelin $\mathrm{A}$ receptor $\left(\mathrm{ET}_{\mathrm{A}}\right)$ in the cortex and medulla were similar in both cirrhotic and control rats (Table 2). Scatchard analysis revealed only one type of $\mathrm{ET}_{\mathrm{A}}$ and $\mathrm{ET}_{\mathrm{B}}$ binding site in the renal medulla and cortex of control and cirrhotic rats (Figure 2). The binding constants were equal in all test groups (data not shown). In accordance with the Scatchard data showing an overexpression of the $\mathrm{ET}_{\mathrm{B}}$ in the renal medulla, receptor autoradiography (Figure 5) demonstrated an increased density of the $\mathrm{ET}_{\mathrm{B}}$ in medullary collecting duct cells of rats with liver cirrhosis (Cir: 19 \pm 4 silver grains/cell; Con: $9 \pm 3$ silver grains/ cell; $n=8 ; P<0.01$ ). The densities of both the $\mathrm{ET}_{\mathrm{A}}$ and $\mathrm{ET}_{\mathrm{B}}$ were similar in the glomeruli and blood vessels of cirrhotic and control rats (data not shown).

The highest endothelin-1 concentrations were observed in the renal medulla of cirrhotic rats. (Cir: $271 \pm 68 \mathrm{pg} / \mathrm{g}^{-1}$ wet wt., Con: $153 \pm 36 \mathrm{pg} \mathrm{g}^{-1}$ wet wt. $n=8 ; P<0.01$, Table 2). The plasma endothelin-1 concentrations were also increased significantly $(P<0.05)$ in cirrhotic compared to control rats (Table 3). Tissue endothelin concentrations were equal in normal and cirrhotic liver (Table 3).

GFR was slightly decreased in cirrhotic rats but not altered after either the lower or the higher dose of bosentan treatment in cirrhotic or control rats (Table 1). Both dosages of bosentan (6 and $100 \mathrm{mg} \mathrm{kg}^{-1}$ day $^{-1}$ ) decreased sodium excretion to a similar extent in both cirrhotic and control rats. However, only the higher dose of bosentan led to a significant decrease in sodium excretion. The decrease achieved with the lower dosage was not significant (Figure 4). Water excretion, on the other hand, was reduced by 6 and $100 \mathrm{mg} \mathrm{kg}^{-1}$ day $^{-1}$ bosentan in cirrhotic rats only (Cir + vehicle: $12.5 \pm 2.2 \mathrm{ml} \mathrm{d}^{-1}$,

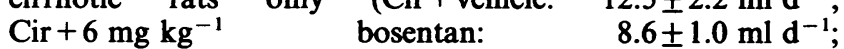
$\mathrm{Cir}+100 \mathrm{mg} \mathrm{kg}^{-1}$ bosentan: $7.4 \pm 0.6 \mathrm{ml} \mathrm{d}^{-1}$, Figure 3). Urinary $\mathrm{pH}$ was similar in control rats and rats with liver cirrhosis (Cir: pH: $7.0 \pm 1.1$; Con: $\mathrm{pH}: 7.2 \pm 1.2 ; n=10$ ) and was not affected by bosentan treatment.

\section{Discussion}

Our study revealed an overexpression of the endothelin B receptor $\left(\mathrm{ET}_{\mathrm{B}}\right)$ in inner medullary tubules of rats with $\mathrm{CCl}_{4}$ induced liver cirrhosis, whereas the density of the $\mathrm{ET}_{\mathrm{B}}$ in the cortex and of the endothelin A receptor $\left(\mathrm{ET}_{\mathbf{A}}\right)$ in the cortex and medulla were similar in both cirrhotic and control rats. The highest endothelin-1 concentrations were also observed in the renal medulla of cirrhotic rats. The GFR was decreased in cirrhotic rats but not altered after bosentan treatment in either

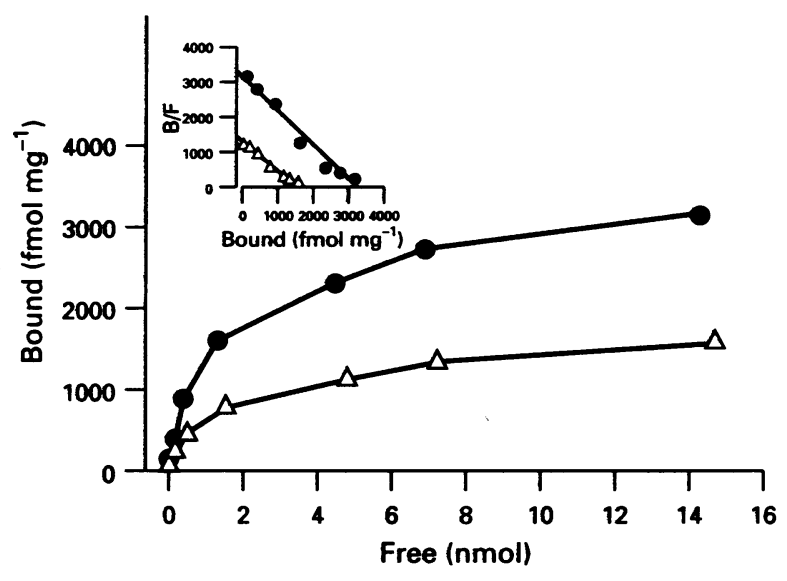

Figure $2 \mathrm{ET}_{\mathrm{B}}$ receptor expression in the renal medulla. The figure shows a representative experiment of $\left[{ }^{125} \mathrm{I}\right]-\mathrm{ET}-1$ specific binding after blocking the ET $_{\mathrm{A}}$ with $\mathrm{BQ123}$ to membranes isolated from the renal medulla of a control $(\Delta)$ and a cirrhotic (O) rat. Scatchard transformations of binding data (inset) suggest only one type of binding site for the $\mathrm{ET}_{\mathrm{B}}$ in both control and cirrhotic rats. Nonspecific binding was determined in the presence of unlabelled ET- 1 as described under Methods and was always less then $10 \%$ of total binding.

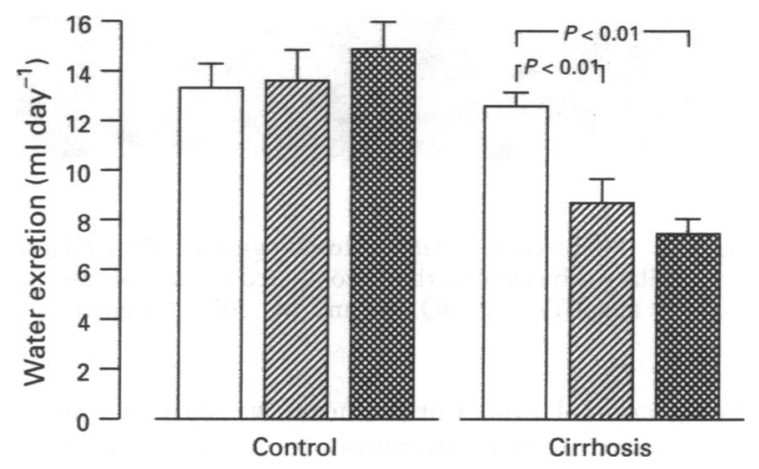

Figure 3 Water excretion was reduced by bosentan in cirrhotic rats only $(n=10 ; P<0.01)$. Bosentan had no influence at all on water excretion in control rats. The rats received bosentan 6 (hatched columns) and 100 (cross-hatched columns) $\mathrm{mg} \mathrm{kg}^{-1}$ day $^{-1}$ respectively or vehicle (open column) by gastric gavage (means \pm s.e.mean).

Table 2 Endothelin receptor density $\left(B_{\max }\right)$ and tissue endothelin-1 concentration in the renal cortex and medulla in control and cirrhotic rats

\begin{tabular}{lcccc} 
& \multicolumn{2}{c}{ Renal cortex } & \multicolumn{2}{c}{ Renal medulla } \\
& Control & $\begin{array}{c}\text { Liver } \\
\text { cirrhosis }\end{array}$ & Control & $\begin{array}{c}\text { Liver } \\
\text { cirrhosis }\end{array}$ \\
& $153 \pm 37$ & $143 \pm 24$ & $153 \pm 36$ & $271 \pm 68^{\#}$ \\
Tissue ET-1 $_{\text {ET }_{\text {A }}\left(\mathrm{fmol} \mathrm{mg} \mathrm{mg}^{-1}\right)}$ & $355 \pm 78$ & $312 \pm 45$ & $599 \pm 59$ & $677 \pm 54$ \\
$\mathrm{ET}_{\mathrm{B}}(\mathrm{fmol} \mathrm{mg-1)}$ & $501 \pm 76$ & $509 \pm 50$ & $1695 \pm 255$ & $2775 \pm 299^{\#}$
\end{tabular}

The $\mathrm{ET}_{\mathrm{al}}$ and $\mathrm{ET}_{\mathrm{B}}$ receptor density was derived from Scatchard plots of $\left[{ }^{125} \mathrm{I}\right]-\mathrm{ET}-1$ binding studies according to Methods. Nonspecific binding was assessed in the presence of $5 \mu \mathrm{mol} 1^{-1}$ of unlabelled ET-1. It ranges between $5-10 \%$. Samples from crude plasma membranes were used at a concentration of $0.53 \mathrm{mg}$ of protein $\mathrm{ml}^{-1}$. Tissue-immunoreactive endothelin-1 (ET-1) was determined with a commercial endothelin-1 radioimmunoassay kit. Values are means \pm s.d. of 8 separate animals in each group. $\#_{\text {indicates } P<0.01}$ compared to control rats. 
Table 3 Plasma and liver tissue ET-1 concentration in control and cirrhotic rats

\begin{tabular}{|c|c|c|}
\hline & $\begin{array}{l}\text { Controls } \\
(n=6)\end{array}$ & $\begin{array}{l}\text { Liver cirrhosis } \\
\quad(n=6)\end{array}$ \\
\hline Plasma ET-1 (pg ml-1) & $19.8 \pm 5.2$ & $30.1 \pm 3.9^{\#}$ \\
\hline $\begin{array}{l}\text { Plasma ET-1 after } 100 \mathrm{mg} \mathrm{kg}^{-1} \\
\text { day }^{-1} \text { bosentan treatment } \\
\left(\mathrm{pg} \mathrm{ml} \mathrm{ml}^{-1}\right)\end{array}$ & $23.7 \pm 6.8$ & $33.7 \pm 6.2^{\#}$ \\
\hline Liver tissue ET-1 $\left(\mathrm{pg} \mathrm{g}^{-1}\right)$ & $59 \pm 5$ & $53 \pm 9$ \\
\hline
\end{tabular}

Liver tissue and plasma immunoreactive endothelin-1 (ET1) was determined using a commercial endothelin-1 radioimmunoassay kit. Bosentan $\left(100 \mathrm{mg} \mathrm{kg}^{-1} \mathrm{day}^{-1}\right)$ was given by gastric gavage. Values are means \pm s.d. of 8 separate animals in each group. \#indicates $P<0.05$ compared to control rats.

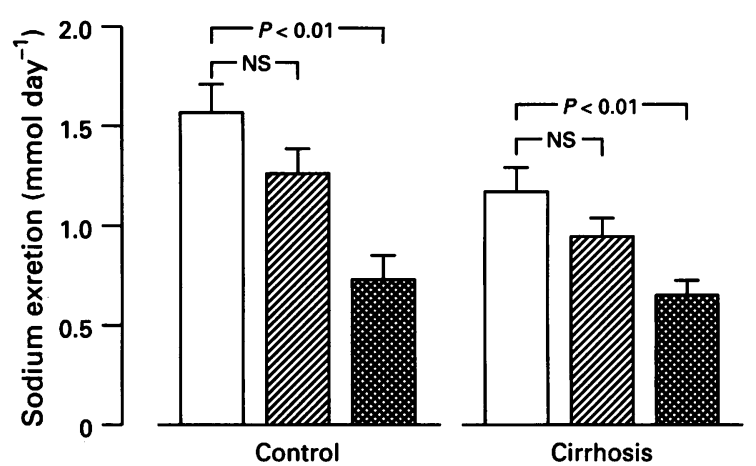

Figure 4 The mixed (A/B) endothelin receptor antagonist bosentan decreased sodium excretion to a similar extent in both cirrhotic and control rats. Bosentan 6 (hatched columns) and 100 (cross-hatched columns) $\mathrm{mg} \mathrm{kg}^{-1} \mathrm{day}^{-1}$ respectively or vehicle (open columns) was given by gastric gavage $(n=10$; means \pm s.e.mean).
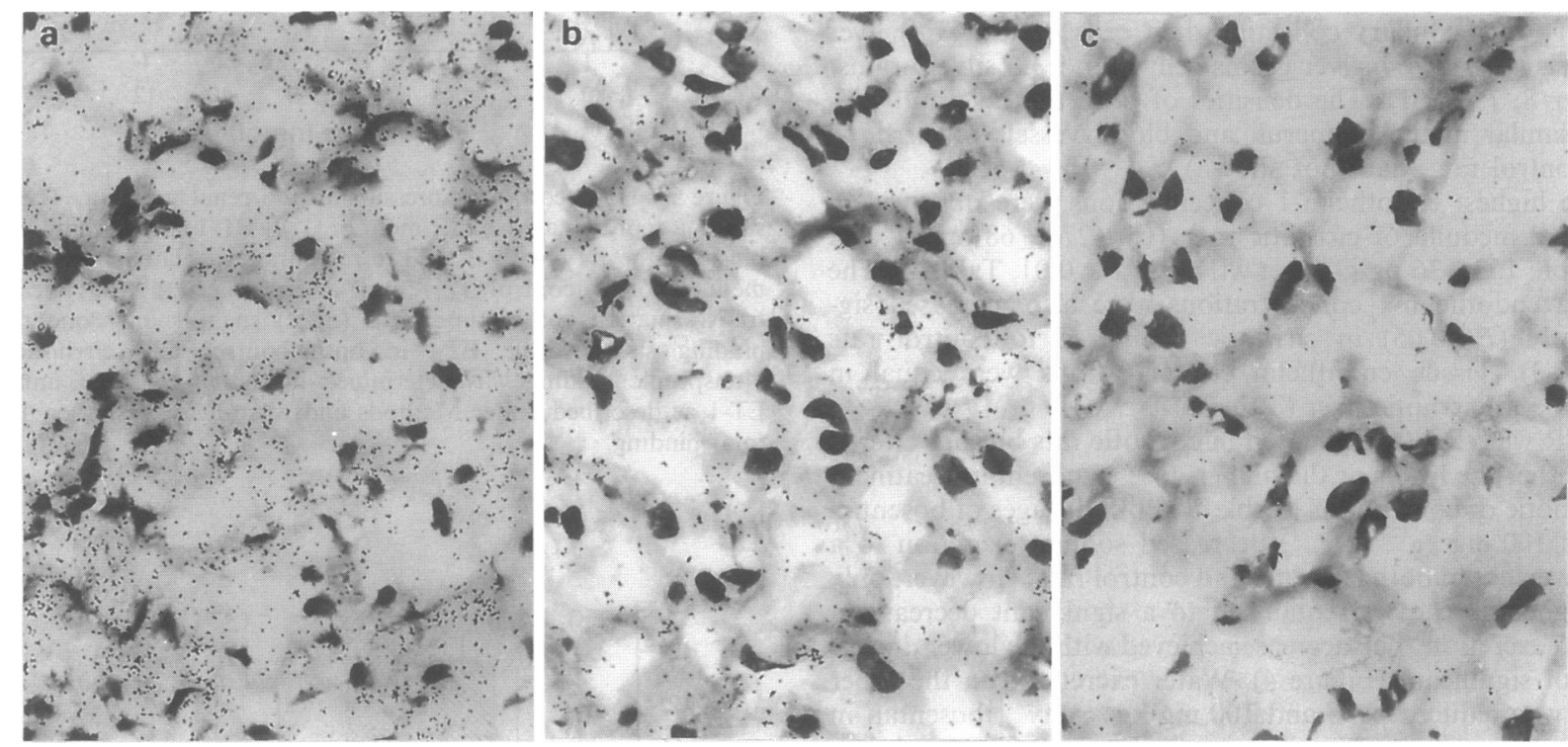

Figure 5 Microscopic in vitro autoradiography of the $\mathrm{ET}_{\mathrm{B}}$ receptor in rat kidneys showing an upregulation of $\mathrm{ET}_{\mathrm{B}}$ receptor protein in medullary tubules of cirrhotic compared to control rats: (a) cirrhotic rat; (b) control rat and (c) nonspecific binding after blocking the $\mathrm{ET}_{\mathrm{A}}$ and $\mathrm{ET}_{\mathrm{B}}$ with $\mathrm{BQ} 123$ and $\mathrm{BQ}$ 3020. (original magnification $830 \times$ ).

cirrhotic or control rats. Furthermore, we showed that bosentan decreased sodium excretion to a similar extent in both cirrhotic and control rats, whereas water excretion was significantly reduced by bosentan in cirrhotic rats only.

\section{Plasma ET-1 concentrations in liver cirrhosis}

It is well known that plasma endothelin concentrations are significantly increased in rats as well as in patients with liver cirrhosis and ascites and that the increased plasma endothelin concentrations are associated with kidney dysfunction (Claria et al., 1991a; Uchihara et al., 1992; Asbert et al., 1993; Moller et al., 1993; Nanji et al., 1994). The precise mechanisms of the elevated plasma endothelin concentrations and their pathophysiological role in cirrhosis remain to be clarified. However, several points should be addressed in this context: (i) Circulating endotoxin, as discussed later, is increased both in rats (Nolan, 1975; Yoshimura et al., 1993) and patients with liver cirrhosis and stimulates endothelin synthesis (Vemulapalli et al., 1991). A reduced hepatic ET-1 clearance seems to be unlikely (Asbert et al., 1993). (ii) Increased plasma endothelin concentrations were reported in patients and experimental models with heart failure, hypertension, chronic and acute renal failure without impaired liver function, and cardiogenic shock
(Leppaluoto et al., 1992; Sokolovsky, 1992; Lüscher et al., 1993), indicating that elevated plasma ET-1 concentrations are a rather nonspecific parameter. We suggest that immunoreactive plasma concentrations reflect a spillover from the tissue endothelin system. (iii) We did not see a fall of mean arterial blood pressure after blocking the $\mathrm{ET}_{\mathrm{A}}$ and $\mathrm{ET}_{\mathrm{B}}$ receptors with bosentan, which indicates that the circulating endothelin as well as the paracrine endothelin system are not involved in the maintenance of arterial blood pressure in cirrhotic rats (Table 1). (iv) Bosentan treatment increased plasma immunoreactive ET-1 in both cirrhotic and control rats (Table 3). Löffler et al. (1993) analysed the bosentan analogue Ro 46-2005 and also observed increased plasma immunoreactive ET-1 after Ro 462005 treatment. He suggested that Ro 46-2005 induced a displacement of ET-1 from the endothelial $\mathrm{ET}_{\mathrm{B}}$ because the elevation of plasma immunoreactive ET-1 occurred very rapidly after treatment with the endothelin receptor antagonist. However, ET-1 gene expression could be increased by blocking the $\mathrm{ET}_{\mathrm{B}}$ on endothelial cells with bosentan, because $\mathrm{ET}_{\mathrm{B}}$ stimulates nitric oxide formation in endothelial cells. Nitric oxide, via cyclic GMP, is a very potent inhibitor of ET-1 gene expression (Lüscher et al., 1993). Therefore, blocking the $\mathrm{ET}_{\mathrm{B}}$ may increase the ET-1 mRNA transcription rate. 
Stimulation of ET-1 and $E T_{B}$ in the renal medulla of rats with $\mathrm{CCl}_{4}$-induced liver cirrhosis

This study revealed a significantly increased $\mathrm{ET}_{\mathrm{B}}$ density and tissue ET-1 concentration in the renal medulla of rats with liver cirrhosis, indicating an upregulation of the paracrine endothelin system in the renal medulla of these animals (Table 2 , Figures 2 and 5). This increased synthesis of endothelin in the renal medulla of cirrhotic rats is probably due to the mechanisms discussed below. Endotoxin, a well-known stimulus of ET-1 synthesis (Vemulapalli et al., 1991), is increased in the kidneys of rats with $\mathrm{CCl}_{4}$-induced liver cirrhosis (Nolan 1975; Yoshimura et al., 1993) as well as in cirrhotic patients (Triger, 1991). The endotoxaemia leading to an increased tissue concentration of endotoxin in rats with liver cirrhosis is thought to result from the combination of an overflow of endotoxin due to decreased detoxifying activity of the liver, a breakdown of the intestinal mucosa barrier due to a diminished secretion of bile acid and changes in bacterial flora, as well as an efflux of portal endotoxin into the systemic circulation due to short-circuits between the portal and systemic circulation (Yoshimura et al., 1993). Second, patients (and rats) with end-stage liver cirrhosis often show a vasoconstriction of the renal arteries (Epstein, 1988) leading to tissue hypoxia. Hypoxia is a well-known stimulus of endothelin-1 synthesis in the kidney (Lüscher et al., 1993; Kohan, 1993b). On the other hand, an increased synthesis of nitric oxide (NO), which has been implicated in the pathogenesis of hypotension in these animals, was demonstrated in rats with liver cirrhosis (Vallance \& Moncada, 1991; Claira et al., 1992). Nitric oxide is a very potent endogenous inhibitor of endothelin synthesis (Kourembanas et al., 1993) with one exception: the inner medullary collecting duct cell. The inner medullary collecting duct cell is not submitted to the usual control mechanisms. ET-1 production in these cells is under unique control. NO and its second messenger cyclic GMP only mildly decrease medullary ET-1 release (Kohan \& Padilla, 1994) compared to the renal cortex or other tissues. Therefore, endotoxin may increase ET-1 synthesis in the renal medulla, whereas the endotoxin stimulus on ET-1 gene expression in the renal cortex is suppressed by nitric oxide. The mechanisms leading to an $\mathrm{ET}_{\mathbf{B}}$ overexpression in the renal medulla of cirrhotic rats are as yet unknown. However, several points should be addressed in this context: (i) Upregulation of a hormone usually causes downregulation of the corresponding hormone receptor and vice versa. This was also demonstrated for the paracrine endothelin system (Clozel et al., 1993; Roubert et al., 1993b). On the other hand, our study showed that there was no such a negative feedback in the renal medulla of rats with liver cirrhosis. We found an upregulation of both the ET-1 tissue concentration and the $\mathrm{E}_{\mathrm{B}}$ density in the renal medullar cirrhotic rats. (ii) Well-known stimulants of $\mathrm{ET}_{\mathrm{B}}$ upregulation in rat cultured vascular smooth muscle cells are natriuretic peptides such as the $C$ type natriuretic peptide and atrial natriuretic peptide (Eguchi et al., 1994). Provided that natriuretic peptides also increase the expression of $\mathrm{ET}_{B}$ in renal inner medullary collecting duct cells, the increased plasma levels of natriuretic peptides in rats with liver cirrhosis (Gines et al., 1988; Laffi et al., 1989) may contribute to the $\mathrm{ET}_{\mathrm{B}}$ overexpression. (iii) An upregulation of $\mathrm{ET}_{\mathrm{B}}$ in the renal medulla was observed in rats with acute renal failure after administration of hypertonic glycerol leading to tissue hypoxia (Roubert et al., 1993a). An impaired renal microcirculation with tissue hypoxia is most probably the cause of $\mathrm{ET}_{\mathrm{B}}$ upregulation in this case. An impaired renal microcirculation is also observed in rats with liver cirrhosis. Therefore, we suggest that tissue hypoxia in the kidneys of cirrhotic rats may also contribute to the $\mathrm{ET}_{\mathrm{B}}$ overexpression in the renal medulla. Roubert et al. (1993a) proposed that the pronounced ET $_{B}$ overexpression in the renal medulla of rats with acute renal failure may account for or contribute to functional renal impairment. However, they did not prove this theory using endothelin receptor antagonists.

\section{Effect of bosentan on water and sodium excretion}

Bosentan was chosen to analyse the pathophysiological relevance of the alterations in the paracrine renal endothelin system in cirrhotic rats (increased $\mathrm{ET}_{\mathbf{B}}$ density within the medullary tubules and increased ET-1 tissue concentration in the renal medulla), because it was shown that bosentan did not influence the renal blood flow, the renal vascular resistance or the glomerular filtration rate in conscious chronically instrumented rats (Hocher et al., 1995) and dogs (Teerlink et al., 1995) thus allowing an independent analysis of tubular functions, whereas ET-1 and $\mathrm{ET}_{\mathrm{B}}$ agonists like sarafotoxin $6 \mathrm{c}$ (Warner et al., 1993) markedly decreased renal blood flow thus not allowing an independent analysis of tubular functions. Bosentan differs in its in vivo potency in blocking $\mathrm{ET}_{\mathrm{A}^{-}}$and $\mathrm{ET}_{\mathrm{B}^{-}}$ mediated effects. Blockade of ET-1-induced $\mathrm{E}_{\mathrm{A}}$-mediated effects requires higher dosages of bosentan compared to the blockade

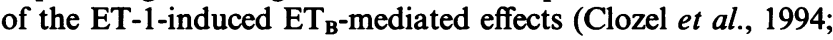
Hocher et al., 1995). The reasons for these observations are not yet clear. Clozel et al. (1994) suggested that bosentan reaches effective concentrations in the $\left(\mathrm{ET}_{\mathrm{B}}\right.$-rich) endothelial layer more easily than in the $\left(\mathrm{ET}_{\mathrm{A}}\right.$-rich) media of blood vessels. In any case, use of lower and higher dosages of bosentan makes it possible to

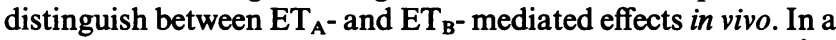
recent study, we demonstrated that as little as $3-10 \mathrm{mg} \mathrm{kg}^{-1}$ of bosentan, i.v., resulted in a markedly decreased $\left(\mathrm{ET}_{\mathrm{B}}\right.$-mediated ) depressor response to ET-1, whereas the pressor response $\left(\mathrm{ET}_{\mathrm{A}^{-}}\right.$mediated) was not altered. Use of $100 \mathrm{mg} \mathrm{kg}^{-1}$ of bosentan i.v., on the other hand, blocked both the $\mathrm{ET}_{\mathrm{A}^{-}}$and $\mathrm{ET}_{\mathrm{B}^{-}}$-mediated responses to ET-1 (Hocher et al., 1995). Based on these pharmacological characteristics of bosentan, we demonstrated in our study using both dosages of bosentan that the low bosentan dosage reduced water excretion in cirrhotic rats to an extent similar to that achieved with the higher one, suggesting that the bosentan effect on water excretion is $\mathrm{ET}_{\mathrm{B}}$-mediated. The additional blockade of $\mathrm{ET}_{\mathrm{A}}$ by the higher dose of bosentan obviously has no additive effect.

The decreased water excretion in cirrhotic rats after bosentan treatment may be due to the well-known endothelin-1induced, ET $_{\mathbf{B}}$-mediated inhibition of vasopressin-induced water reabsorption (Edwards et al., 1993). Via $\mathrm{ET}_{\mathbf{B}}$ receptors endothelin-1 inhibits vasopressin-dependent cyclic adenosine $3^{\prime}: 5^{\prime}$-monophosphate accumulation and vasopressin-stimulated water permeability in the collecting duct, thus decreased urine osmolarity and increasing urine flow (Kohan, 1993a). Cirrhotic rats had elevated plasma vasopressin levels with a resultant vasopressin-dependent decrease in water excretion (Arroyo et al., 1988; Claira et al., 1991b) and also exhibited an increased $\mathrm{ET}_{\mathrm{B}}$ density in the renal medulla, as shown in our study by two independent methods. Using bosentan, we blocked the $\mathrm{ET}_{\mathrm{B}}$-mediated inhibitory effect of endothelin-1 on vasopressin-induced water reabsorption. Such a blockade of $\mathrm{ET}_{\mathrm{B}}$ would result in less autocrine inhibition of vasopressindependent water transport with a subsequent decrease of urine flow. Therefore, the upregulation of medullary $\mathrm{ET}_{\mathrm{B}}$ in rats with liver cirrhosis may be a protective mechanism against water retention in these animals.

Since we found no differences of glomerular $\mathrm{ET}_{\mathrm{A}}$ and $\mathrm{ET}_{\mathrm{B}}$ expression between cirrhotic and normal rats, it was not surprising that the effects of blocking glomerular $\mathrm{ET}_{\mathrm{A}}$ and $\mathrm{ET}_{\mathrm{B}}$ with bosentan in cirrhotic and normal rats were similar with respect to glomerular filtration rate. The lower dose of bosentan (mainly $\mathrm{ET}_{\mathrm{B}}$ blockade, see above) decreased sodium excretion non-significantly, whereas the higher one $\left(\mathrm{ET}_{\mathrm{A}}\right.$ and $\mathrm{ET}_{\mathrm{B}}$ blockade) resulted in a significant reduction of sodium excretion in both cirrhotic and control rats, indicating that sodium excretion seems to be $\mathrm{ET}_{\mathrm{A}}$-mediated. $\mathrm{An} \mathrm{ET}_{\mathrm{A}}$-dependence of tubular sodium excretion was also reported by Gellai et al. (1994). $\mathrm{Na}^{+}-\mathrm{K}^{+}$-ATPase and $\mathrm{Na}^{+} / \mathrm{PO}_{4}$-exchanger seem to play a major role in these $\mathrm{ET}_{\mathrm{A}}$-mediated effects of endothelin-1 (Garvin \& Sanders, 1991).

In conclusion, this study demonstrated that both the tissue endothelin concentration and $\mathrm{ET}_{\mathrm{B}}$ density are significantly 
increased in the renal medulla of rats with $\mathrm{CCl}_{4}$-induced liver cirrhosis compared to control rats. Blockade of this activated endothelin system with the orally active endothelin receptor antagonist, bosentan, resulted in a decreased water excretion in cirrhotic rats, indicating that the observed alterations in the renal paracrine endothelin system contribute to the regulation of water excretion in rats with liver cirrhosis and ascites.
We wish to thank Prof. Dr. F. Körber, Inst. für Molekularbiologie und Biochemie; Freie Universität Berlin, Germany, for helpful discussion and critical reading of the manuscript. The technical assistance of Mrs S. Schiller is greatly appreciated.

\section{References}

ARAI, H., HORI, S., ARAMORI, I., OHKUBO, H. \& NAKANISHI, S. (1990). Cloning and expression of a cDNA encoding an endothelin receptor. Nature, 348, 730-732.

ARROYO, V., BERNARDI, M., EPSTEIN, M., HENRIKSEN, J.H. SCHRIER, R.W. \& RODES J. (1988). Pathophysiology of ascites and functional renal failure in cirrhosis. J. Hepatol., 6, 239-257.

ASBERT, M., GINES, A., GINES, P., JIMENEZ, W., CLARIA, J., SALO, J., ARROYO, V., RIVERA, F. \& RODES, J. (1993). Circulating levels of endothelin in cirrhosis. Gastroenterology, 104, 1485-91.

BOLGER, G.T., LIARD, F., JODOIN, A. \& JARAMILLO, J. (1991). Vascular reactivity, tissue levels, and binding sites for endothelin: a comparison in the spontaneously hypertensive and WistarKyoto rats. Can. J. Physiol. Pharmacol., 69, 406-413.

CLARIA, J., JIMENEZ, W., ARROYO, V., CASTRO, A., ASBERT, M., ROS, J., RIVERA, F. \& RODES, J. (1991a). Doses of endothelin have natriuretic effects in conscious rats with cirrhosis and ascites. Kidney Int., 40, 182-7.

CLARIA, J., JIMENEZ, W., ARROYO, V., LA-VILLA, G., LOPEZ, C., ASBERT, M., CASTRO, A., GAYA, J., RIVERA, F. \& RODES, J. (1991b). Effect of $V_{1}$-vasopressin receptor blockade on arterial pressure in conscious rats with cirrhosis and ascites. Gastroenterology, 100, 494-501.

ClARIA, J., JIMENEZ, W., ROS, J., ASBERT, M., CASTRO, A., ARROYO, V., RIVERA, F. \& RODES, J. (1992). Pathogenesis of arterial hypotension in cirrhotic rats with ascites; role of endogenous nitric oxide. Hepatology, 15, 343-349.

CLOZEL, M., BREU, V., GRAY, G.A., KALNA, B., LÖFFLER, B.M., BURRI, K., CASSAL, J.M., HIRTH, G., MÜLLER, M., NEIDHART, W. \& RAMUZ, H. (1994). Pharmacological characterization of bosentan, a new potent orally active non-peptide endothelin receptor antagonist. J. Pharmacol. Exp. Ther., 270, 228-235.

CLOZEL, M., LOFFLER, B.M., BREU, V., HILFIGER, L. \& MAIRE, J.P. \& BUTSCHA, B. (1993). Downregulation of endothelin receptors by autocrine production of endothelin-1. Am. J. Physiol., 265 (1 Pt 1), C188-92.

EDWARDS, R.M., STACK, EJ., PULLEN, M. \& NAMBI, P. (1993). Endothelin inhibits vasopressin action in rat inner medullary collecting duct via the ETB receptor. J. Pharmacol. Exp. Ther., 267, $1028-1033$.

EGUCHI, S., HIRATA, Y., IMAI, T. \& MARUMO, F. (1994). C-type natriuretic peptide upregulates vascular endothelin type B receptors. Hypertension, 23, 936-940.

EPSTEIN, M. (1988). Hepatorenal syndrome. In The Kidney in Liver Disease. ed. Epstein, M. 3rd edn. pp. 3-30. Baltimore; Williams \& Williams.

GANDHI, C.R., BEHAL, R., HARVEY, S., NOUCHI, T. \& OLSON, M. (1992). Hepatic effects of endothelin. Biochem. J., 287, 897-904.

GANDHI, C.R., HARVEY, S.A. \& OLSON, M. (1993). Hepatic effects of endothelin: metabolism of [125I]endothelin-1 by liver-derived cells. Arch. Biochem. Biophys.,305, 38-46.

GARVIN, J. \& SANDERS, K. (1991). Endothelin inhibits fluid and bicarbonate transport in part by reducing $\mathrm{Na}^{+}-\mathrm{K}^{+}$-ATPase activity in the rat proximal straight tubule. J. Am. Soc. Nephrol., 2, 976-982.

GELlAi, M., DEWOLF, R., PULLEN, M. \& NAMBI, P. (1994). Distribution and functional role of renal ET receptor subtypes in normotensive and hypertensive rats. Kidney Int., 46, 12871294.

GINES, P., JIMENEZ, W., ARROYO, V., NAVASA, M., LOPEZ, C., TITO, L., SERRA, A., BOSCH, J., SANZ, G. \& RIVERA, F. (1988). Atrial natriuretic factor in cirrhosis with ascites. Plasma levels, cardiac release and splanchnic extraction. Hepatology, 8, 636-642.

GRETZ, N., ECKER-TSCHIRNER, K.H., KÜHNLE, K.F., VON-DAHL, K., KIRSCHFINK, M., DRESCHER, P., LASSERRE, J.J. \& STRAUCH, M. (1990). Practicability of the inulin plasma singleshot clearance. Contrb. Nephrol., 81, 220-228.
GROSS, P., RENN, C., WALDHERR, R., SEIFERT, M., BAEHR, R. \& HOCHER, B. (1993). Potential role of endothelin in the physiological and pathological regulation of kidney function. Endothelium, 1, 71-83.

HAENDLER, B., HECHLER, U. \& SCHLEUNING, W.D. (1992) Molecular cloning of human endothelin (ET) receptors ETA and ETB. J. Cardiovasc. Pharmacol., 20 Suppl 12:S1-4.

HOCHER, B., MERKER, H.J., DÜRR, J.A., SCHILLER, S., GROSS, P. \& HENSEN, J. (1992a). Internalization of $V_{2}$-vasopressin receptors

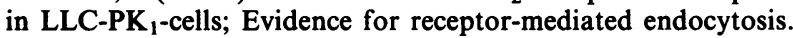
Biochem. Biophys. Res. Commun., 186, 1376-1383.

HOCHER, B., ROHMEISS, P., ZART, R., DIEKMANN, F., BRAUN, C., KOPPENHAGEN, K., BAUER, C., DISTLER, A. \& GRETZ, N. (1995). Distribution of endothelin receptor subtypes in the rat kidney. Renal and haemodynamic effects of the mixed (A/B) endothelin receptor antagonist bosentan. Eur. J. Clin. Chem. Clin. Biochem., 33, 463-472.

HOCHER, B., RUBENS, C., HENSEN, J. GROSS, P. \& BAUER, C. (1992b). Intracellular distribution of endothelin-1 receptors in rat liver cells. Biochem. Biophys. Res. Commun., 184, 498-503.

KOHAN, D.E. (1993a). Autocrine role of endothelin in rat inner medullary collecting duct: inhibition of AVP-induced cAMP accumulation. J. Cardiovasc. Pharmacol., 22, Suppl 8: S174-9.

KOHAN, D.E (1993b). Endothelins in the kidney: physiology and pathophysiology. Am. J. Kidney Dis., 22, 493-510.

KOHAN, D.E., \& PADILLA, E. (1994). Endothelin-1 production by rat inner medullary collecting duct: effect of nitric oxide, cGMP, and immune cytokines. Am. J. Physiol., 266, F291-F297.

KOUREMBANAS, S., MCQUILLAN, L.P., LEUNG, G.K. \& FALLER, D.V. (1993). Nitric oxide regulates the expression of vasoconstrictors and growth factors by vascular endothelium under both normoxia and hypoxia. J. Clin. Invest., 93, 99-104.

KUEHNLE, H.F., DAHL, D.V. \& SCHMIDT, F.H. (1992). Fully enzymatic determination in small volume samples without deproteinization. Nephron., 62, 104-107.

KUMAR, C., MWANGI, V., NUTHULAGANTI, P., WU, H.L., PULLEN, M., BRUN, K., AIYAR, H., MORRIS, R.A., NAUGHTON, R. \& NAMBI, P. (1994). Cloning and characterization of a novel endothelin receptor from Xenopus heart. J. Biol. Chem., 269, $13414-13420$

LAFFI, G., PINZANI, M., MEACCI, E., LA VILLA, G., RENZI, D. BALDI, E., COMINELLI, F., MARRA, F. \& GENTILINI, P.I. (1989) Renal hemodynamic and natriuretic effects of human atrial natriuretic factor infusion in cirrhosis with ascites. Gastroenterology, 96, 167-177.

LEPPALUOTO, J. \& RUSKOAHO, H. (1992). Endothelin peptides: biological activities, cellular signalling and clinical significance. Ann. Med., 24, 153-161.

LÖFFLER, B.M., BREU, V. \& CLOZEL, M. (1993). Effect of different endothelin receptor antagonists and of the novel non-peptide antagonist Ro 46-2005 on endothelin levels in rat plasma. FEBS Lett., 333, $108-110$.

LOWRY, O.H., ROSEBROUGH, N.J., FARR, A.L. \& RANDALL, R.J. (1951). Protein measurement with the Folin reagent. J. Biol. Chem., 193, 265-275.

LÜSCHER, T.F., OEMAR, B.S., BOULANGER, C.M. \& HAHN, A.W.A. (1993). Molecular and cellular biology of endothelin and its receptor-Part I (Part II). J. Hypertens., 11, 7-11, 11, 121-126.

MCLEAN, E.K., MCLEAN, A.E.M. \& SUTTON, P.M. (1969). An improved method for producing cirrhosis of the liver in rats by simultaneous administration of carbon tetrachloride and phenobarbitone. Br. J. Exp. Pathol., 50, 502-506.

MOLLER, S., EMMELUTH, C. \& HENRIKSEN, J.H. (1993). Elevated circulating plasma endothelin-1 concentrations in cirrhosis. $J$. Hepatol., 19, 285-90. 
NAMBI, P., PULLEN, M. \& CONTINO, L.C. (1990). Upregulation of renal endothelin receptors in rats with cyclosporine $A$-induced nephrotoxicity. Eur. J. Pharmacol., 187, 113-116.

NAMBI, P., PULLEN, M., WU, H.L., AIYAR, N., OHLSTEIN, E.H. \& EDWARDS, R.M. (1992). Identification of endothelin receptor subtypes in human renal cortex and medulla using subtypeselective ligands. Endocrinology, 131, $1081-1086$.

NANJI, A.A., KHWAJA, S., KHETTRY, U. \& SADRZADEH, S.M. (1994). Plasma endothelin levels in chronic ethanol fed rats: relationship to pathologic liver injury. Life Sci., 54, 423-8.

NOLAN, J.P. (1975). The role of endotoxin in liver injury. Gastroenterology, 69, 1346-1356.

ROUBERT, P., CORNET, S., PLAS, P., GUILMARD, C., PIROTZKY, E. CHABRIER, P.E. \& BRAQUET, P. (1993a). Upregulation of renal endothelin receptors in glycerol-induced acute renal failure in the rat. J. Cardiovasc. Pharmacol., 22, Suppl 8: S303-5.

ROUBERT, P., VIOSSAT, I., LONCHAMPT, M.O., CHAPELAT, M., SCHULZ, J., PLAS, P., GILLARD-ROUBERT, V., CHABRIER, P.E. \& BRAQUET, P. (1993b). Endothelin receptor regulation by endothelin synthesis in vascular smooth muscle cells; effects of dexamethasone and phosphoramidone. J. Vasc. Res., 30, 139144.

SOKOLOVSKY, M. (1992). Endothelins and sarafotoxins: physiological regulation receptor subtypes and transmembrane signaling. Pharmacol. Ther., 54, 129-149.

TEERLINK, J.R., CARTEAU, J.P., SPRECHER, U., LÖFFLER, B.M., CLOZEL, M. \& CLOZEL, J.P. (1995). Role of endogenous endothelin in normal hemodynamic status of anesthetized dogs. Am. J. Physiol., 268, H432-H440.
TRIGER, D.R. (1991). Endotoxamia in liver disease-time for reappraisal? J. Hepatol., 12, 136-138.

UCHIHARA, M., IZUMI, N., SATO, C. \& MARUMO, F. (1992). Clinical significance of elevated plasma endothelin concentration in patients with cirrhosis. Hepatology, 16, 95-9.

VALLANCE, P. \& MONCADA, S. (1991). Hyperdynamic circulation in cirrhosis: a role for nitric oxide. Lancet, 337, 776- 778.

VEMULAPALLI, S., CHIU, P.J., RIVELLI, M., FOSTER, C.J. \& SYBERTZ, E.J. (1991). Modulation of circulating endothelin levels in hypertension and endotoxaemia in rats. J. Cardiovasc. Pharmacol., 18, 895-903.

WARNER, T.D., BATTISTINI, B., ALLCOCK, G.H. \& VANE, J.R. (1993). Endothelin ETA and ETB receptors mediate vasoconstriction and prostanoid release in the isolated kidney of the rat. Eur. J. Pharmacol., 250, 447-453.

YANAGISAWA, M., KURIHARA, H., KIMURA, S., TOMOBE, Y., KOBAYASHI, M., MITSUI, Y., YAZAKI, T. (1988). A novel potent vasoconstrictor peptide produced by vascular endothelial cells. Nature, 332, 411-415.

YOSHIMURA, A., IDEURA, T., SHIRAI, T., TAIRA, T., IWASAKI, S., KITAOKA, T. \& KOSHIKAWA, S. (1993). The distribution of 3Hlabeled endothelin in the kidney of liver cirrhosis. Scand. J. Urol. Nephrol., 27, 295-299.

(Received December 21, 1994 Revised November 11995 Accepted January 18, 1996) 